\title{
Pretranslational regulation of the expression of the lipoprotein lipase $(E C$ 3.1.1.34) gene by dietary fatty acids in the rat
}

\author{
BY M. C. MURPHY, A. ZAMPELAS, S. M. PUDDICOMBE, N. P. FURLONGER, \\ L. M. MORGAN AND C. M. WILLIAMS \\ Nutritional Metabolism Research Group, School of Biological Sciences, University of Surrey, \\ Guildford GU2 $5 \mathrm{XH}$
}

(Received 14 October 1992 - Accepted 29 January 1993)

\begin{abstract}
Although there have been a number of studies of effects of diet and hormones on lipoprotein lipase (EC 3.1.1.34; LPL) activity and levels of LPL mRNA (Raynolds et al. 1990), there have been no studies which have investigated effects of different dietary fatty acids on LPL gene expression. In the present study male Wistar Albino rats were pair-fed diets containing $50 \mathrm{~g}$ fat $/ \mathrm{kg}$ of different fatty acid composition for 2 weeks. The diets fed were (1) a mixed oil (450 g saturated fatty acids, $420 \mathrm{~g}$ monounsaturated fatty acids, $130 \mathrm{~g}$ polyunsaturated fatty acids $/ \mathrm{kg} ; n$ 8), (2) maize oil $(n$ 8), or (3) fish oil $(n$ 8). Animals were killed, RNA was extracted from liver and perirenal and epididymal fat pads, and analysed by 'Northern methodology'. Samples were hybridized to a human cDNA probe for LPL (Gotoda et al. 1989). Two transcripts were identified in epididymal and perirenal adipose tissue which were approximately 3.7 and $1.7 \mathrm{~kb}$ in size. The results suggested that (1) fish oil-fed animals had significantly greater production of LPL mRNA in epididymal adipose tissue compared with maize oilfed animals $(P<0.05)$, (2) maize oil-fed animals had significantly greater production of LPL mRNA in perirenal fat compared with the other dietary groups $(P<0.05)$, (3) expression in the liver was not significant. Rats fed on a fish oil diet had significantly reduced plasma triacylglycerol concentrations compared with the mixed-oil group $(P<0.05)$, but there were no significant differences in plasma cholesterol. The differences in LPL could not be explained directly by the changes in plasma immunoreactive-insulin and glucose-dependent insulinotrophic polypeptide levels in the three groups.
\end{abstract}

Lipoprotein lipase: Fatty acids: Fish oils: Rat

Lipoprotein lipase (EC 3.1.1.34; LPL) is situated on the vascular endothelium and is the major enzyme responsible for the hydrolysis of triacylglycerols (TG) from circulating chylomicrons and very-low-density lipoproteins. The fatty acids released are transported into peripheral cells either for storage as adipose tissue triacylglycerols or for energy utilization. LPL activity is rate limiting in the clearance of circulating triacylglycerol-rich lipoproteins and determines the extent of fat deposition at different adipose tissue sites and fatty acid uptake and oxidation by skeletal and cardiac muscles. LPL is synthesized in most tissues, including adipose, heart, mammary gland and macrophages. In recent years cDNA probes for LPL from many species have been published including chicken, bovine, human, and mouse (Gotoda et al. 1989; Bensadoun, 1991) and their availability allows detailed investigations into the mechanisms of dietary and hormonal influences on this important enzyme. The humoral and dietary control of LPL activity has been examined in a number of species. Much information has indicated that LPL activity in adipose tissue is increased in fed compared with overnight-fasted animals. Rats fed on diets containing highly unsaturated fats have shown decreased circulating triacylglycerol levels and increased 
post-heparin plasma LPL activity (Paik \& Yearick 1978; Groot et al. 1988; Van Heek \& Zilversmit, 1990; Levy et al. 1991); however, there are conflicting results when heparinreleasable activity from tissue is measured. Cryer et al. (1978) found that feeding maize oil increased the LPL activity in epididymal and perirenal adipose tissue compared with the control diet or a beef-tallow diet whereas Shimorura et al. (1990) showed no change in LPL activity in perirenal adipose tissue when comparing the consumption of safflower oil and beef tallow. The polyunsaturated $n-3$ fatty acids, principally eicosapentaenoic and docosahexaenoic acids, have been shown to be potent hypotriacylglyceridaemic agents. Harris (1989) quoted thirty-nine individual references which indicate a lowering of plasma TG in humans fed on fish oils compared with controls, with responses ranging from -1 to $-65 \%$. These findings suggest that feeding fish oils would increase LPL activity but information in the literature is conflicting and incomplete. Harris et al. (1988) measured LPL activity in vitro in post-heparin plasma from subjects fed on fish oils and showed no change in LPL activity; however, the authors did question whether the in vitro method simulated lipolysis in vivo. Haug \& Hostmark (1987) compared the effect of feeding fish oil or coconut oil to rats and showed increased epididymal LPL activity in the fish oil group. Thus, there is strong evidence that dietary fatty acid composition can influence LPL activity; however, there is little understanding of the underlying mechanism to elucidate, for example, whether the effect is substrate or hormone driven. The present study was established to examine the effects of dietary fatty acid composition on LPL gene expression.

\section{METHODS}

Animals

Male Wistar albino rats $(250 \mathrm{~g}$ ) were randomly allocated to three test groups to be pair-fed for 2 weeks on diets containing $50 \mathrm{~g}$ fat $/ \mathrm{kg}$ diet supplied as either maize oil, fish oil or mixed oil containing (g/ $\mathrm{kg}$ ) saturated fatty acid (SFA) 450 , monounsaturated fatty acid (MFA) 420 and polyunsaturated fatty acid (PUFA) 130 to mimic the UK current dietary composition of fatty acids. The fatty acid compositions of the oils are given in Table 1 . The animals were meal-fed before death so that they were in the fed state at the time of tissue removal. One animal from each dietary group was killed on each day of culling. In addition, assays were organized to ensure that tissues or plasma samples from one animal of each dietary group were analysed within the same assay, to eliminate the possibility of interassay variability influencing the results obtained. This involved removing the food at 09.00 hours on the day before death and giving all the day's food at 17.00 hours for consumption overnight before the cull at 09.00 hours on the following morning. The animals were anaesthetized using diethyl ether and blood taken by cardiac puncture. The rats were then killed by cervical dislocation and epididymal fat pads, liver and perirenal adipose tissue dissected.

\section{Measurement of LPL activity}

LPL activity was measured in epididymal adipose tissue by a modified method described by Nilsson-Ehle \& Schotz (1976) using the detection of liberated labelled free fatty acids from a labelled triolein substrate emulsion. The interassay coefficient of variation was $4.9 \%$ at 0.73 and $5.6 \%$ at $2.7 \times 10^{-6} \mu \mathrm{mol}$ oleate $/ \mathrm{min}$ per $\mathrm{mg}$ at $37^{\circ}$.

\section{Measurement of LPL $m R N A$}

Total RNA was extracted by a single-step isolation using an acid guanidinium thiocyanate-phenol-chloroform mixture (Chomczynski \& Sacchi, 1987). Tissues were 
Table 1. Fatty acid composition of the three diets $(\mathrm{g} / \mathrm{kg})$

\begin{tabular}{lrrr}
\hline Fatty acid & Mixed oil & Maize oil & Fish oil \\
\hline $12: 0$ & 107 & 0 & 0 \\
$14: 0$ & 41 & 6 & 71 \\
$16: 0$ & 247 & 140 & 175 \\
$18: 0$ & 32 & 23 & 42 \\
$20: 0$ & 5 & 3 & 0 \\
$14: 1 n-9$ & 0 & 0 & 3 \\
$16: 1 n-9$ & 6 & 3 & 99 \\
$18: 1 n-9$ & 390 & 300 & 129 \\
$20: 1 n-9$ & $T r$ & 2 & 25 \\
$22: 1 n-11$ & $T r$ & 2 & 11 \\
$18: 2 n-6$ & 120 & 500 & 42 \\
$20: 2 n-3$ & 0 & 0 & 44 \\
$18: 3 n-3$ & 5 & 16 & 0 \\
$20: 4 n-6$ & 0 & 0 & 16 \\
$22: 4 n-6$ & 0 & 0 & 12 \\
$20: 5 n-3$ & 0 & 0 & 182 \\
$22: 5 n-3$ & 0 & 0 & 21 \\
$22: 6 n-3$ & 0 & 0 & 128 \\
\hline
\end{tabular}

homogenized on ice in $5 \mathrm{ml}$ portions of a solution ' $\mathrm{D}$ ' containing $4 \mathrm{M} \cdot$ guanidinium thiocyanate, $25 \mathrm{~mm}$-sodium citrate, sarcosyl $(5 \mathrm{~g} / 1)$ and $0 \cdot 1 \mathrm{M}$-2-mercaptocthanol. The homogenate was added to $500 \mu \mathrm{l} 2 \mathrm{M}$-sodium acetate, $5 \mathrm{ml}$ phenol (fresh, water saturated) and $200 \mu \mathrm{l}$ chloroform-isoamyl alcohol $(24: 1, \mathrm{v} / \mathrm{v})$, shaken vigorously and left on ice for $15 \mathrm{~min}$. Following centrifugation at $10000 \mathrm{~g}$ for $20 \mathrm{~min}$ at $4^{\circ}$ the aqueous layer was removed and mixed with an equal volume of propan-2-ol. The tubes were left at $-20^{\circ}$ for $1 \mathrm{~h}$ and recentrifuged at $10000 \mathrm{~g}$ for $20 \mathrm{~min}$ at $4^{\circ}$. The pellet was dissolved in solution ' $\mathrm{D}$ ' $(300 \mu \mathrm{l})$ without mercaptoethanol and precipitated for $1 \mathrm{~h}$ at $-20^{\circ}$ with 2 vol. ethanol. Following centrifugation the precipitate was washed with ethanol $(750 \mathrm{ml} / 1)$, centrifuged again and drained and stored in sodium dodecyl sulphate (SDS; $5 \mathrm{~g} / \mathrm{l}$ ) at $-20^{\circ}$. RNA content was measured by absorption at $260 \mathrm{~nm}$.

Total RNA extracts $(10 \mu \mathrm{m})$ were separated on denaturing agarose gels $(14 \mathrm{~g} / \mathrm{l})$ containing $10 \mathrm{~mm}-3[\mathrm{~N}$-morpholino]propanesulphonic acid (MOPS) and formaldehyde $(0 \cdot 3 \mathrm{ml} / \mathrm{l})$, visualized with ethidium bromide and blotted onto Hybond $\mathrm{N}$ (Amersham, UK) membrane using 10X SSC (150 mM-sodium citrate, $1.5 \mathrm{M}$-sodium chloride; $\mathrm{pH} 7 \cdot 0$ ). Blots were crosslinked under u.v. for $3 \mathrm{~min}$ and baked at $80^{\circ}$ for $2 \mathrm{~h}$. Blots were probed with a subclone of the LPL recombinant supplied by Oka (Gotoda et al. 1987) labelled with [ $\alpha$ $\left.{ }^{32} \mathrm{P}\right] \mathrm{dCTP}$ using a 'Megaprime oligolabelling kit' (Amersham, UK). Prehybridization and hybridization was carried out at $65^{\circ}$ in a rolling oven using solutions modified from Church \& Gilbert (1984) containing 1 mM-EDTA, 0.5 $\mathrm{M}-\mathrm{NaHPO}_{4}(\mathrm{pH} 7 \cdot 2)$ and SDS (70 g/1). Two $30 \mathrm{~min}$ posthybridization washes were carried out at $65^{\circ}$ with a solution containing $1 \mathrm{~mm}$ EDTA, 40 mM-NaHPO $(\mathrm{pH} 7 \cdot 2)$ and $\operatorname{SDS}(50 \mathrm{~g} / 1)$.

The bands were visualized by autoradiography and LPL mRNA quantified by densitometric scanning at $550 \mathrm{~nm}$. Mean values and standard deviations for each tissue and each dietary group were calculated. The intraassay coefficient of variation of the method for liver was $21.2 \%$ and the intraassay variation between duplicates (percentage difference of the means and standard deviations) was 14 (SD 0.4) \%; therefore, all samples in the present study were probed in one run. Differences between dietary groups were identified 


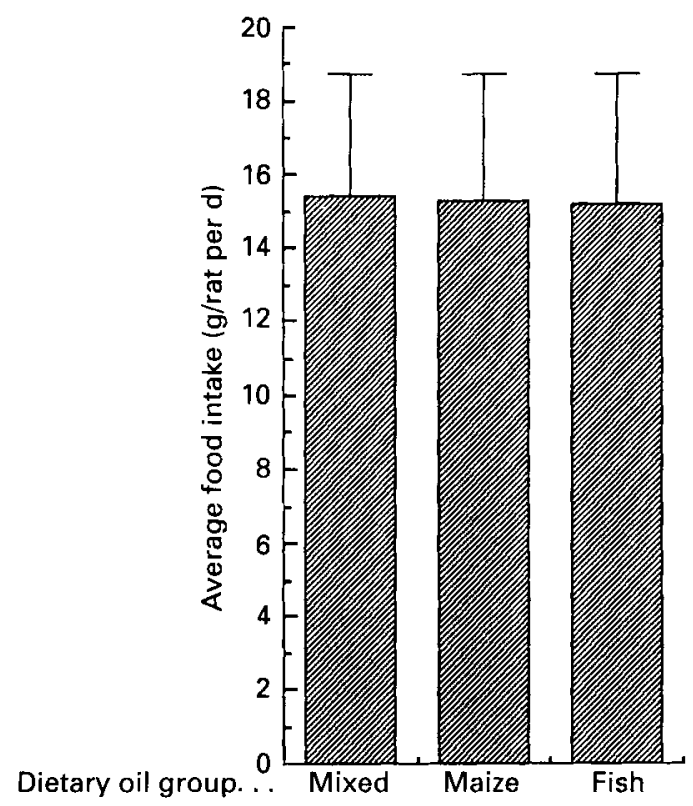

Fig. 1. Average food intake ( $\mathrm{g} / \mathrm{rat}$ per d) of rats pair-fed $50 \mathrm{~g}$ fat $/ \mathrm{kg}$ diets containing mixed, maize or fish oil for 2 weeks. Values are means and standard deviations represented by vertical bars for eight rats per group. For details of dietary treatments, see Table 1 and p. 728 .

by analysis of variance with Duncan's range test to assess level of statistical significance. $P<0.05$ was taken as the lowest level of significance.

\section{Measurement of triacylglycerol (TG) and cholesterol}

Plasma TG and cholesterol levels were assayed spectrophotometrically using kits supplied by Roche. Both tests were enzymic colorimetric analysis using cholesterol esterase (EC 3.1.1.13), cholesterol oxidase $(E C 1.1 .3 .6)$ or glycerol-3-phosphate oxidase (EC 1.1.3.21) respectively. The interassay coefficients of variation were $2.9 \%$ at $2.8 \mathrm{mmol} / 1$ for plasma TG and $4 \%$ at $4.1 \mathrm{mmol} / 1$ for plasma cholesterol measurements.

Measurements of insulin and glucose-dependent insulinotrophic polypeptide (GIP)

Immunoreactive insulin and GIP measurements were carried out using specific radioimmunoassays according to Hampton (1983) and Morgan et al. (1978) respectively. The interassay coefficients of variation were $10.5 \%$ at $40 \mathrm{mU} / 1$ for plasma immunoreactive insulin and $8 \%$ at $360 \mathrm{pmol} / 1$ for GIP measurements.

\section{RESULTS}

The food intake and growth curves are given in Figs. 1 and 2 respectively. All animals gained weight during the study (Fig. 2); although the fish oil group had a slightly higher mean weight gain there were no significant differences between any of the groups. Plasma TG and cholesterol levels are given in Table 2, which shows that fish oils significantly reduced plasma TG as expected $(P<0 \cdot 05)$. Measurements of epididymal LPL activity are given in Fig. 3. Although there was a trend towards increased LPL activity in the fish oil- 


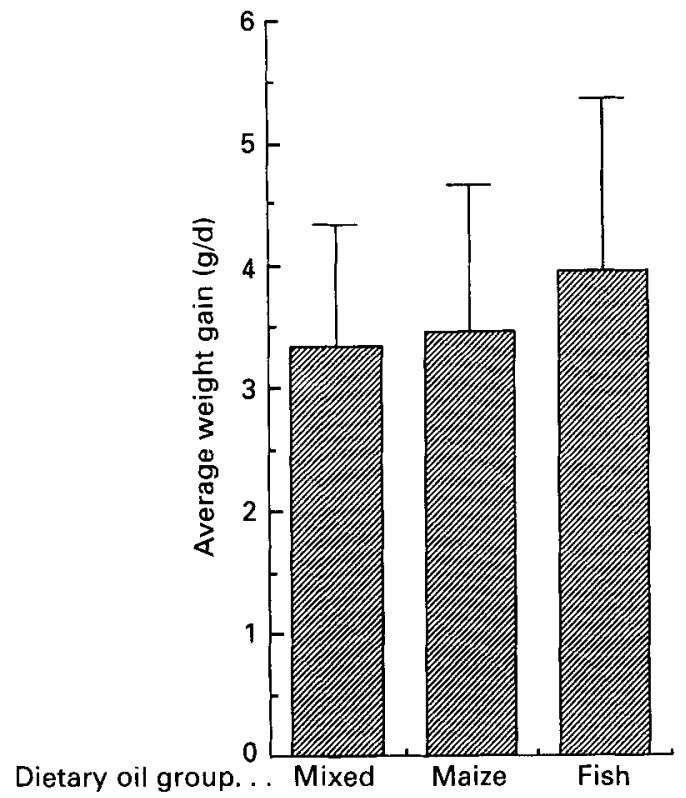

Fig. 2. Average weight gain (g/rat per d) of rats pair-fed $50 \mathrm{~g}$ fat $/ \mathrm{kg}$ diets containing mixed, maize or fish oil for 2 weeks. Values are means and standard deviations represented by vertical bars for eight rats per group. For details of dietary treatments, see Table 1 and p. 728.

Table 2. Effects of fish oil feeding on plasma hormone and lipid concentrations from rats pair-fed $50 \mathrm{~g}$ fat $/ \mathrm{kg}$ diets containing mixed, maize or fish oil for 2 weeks

(Mean values and standard deviations for eight animals/group)

\begin{tabular}{|c|c|c|c|c|c|c|}
\hline & \multicolumn{2}{|c|}{ Mixed oil } & \multicolumn{2}{|c|}{ Maize oil } & \multicolumn{2}{|c|}{ Fish oil } \\
\hline & Mean & SD & Mean & SD & Mean & SD \\
\hline Cholesterol (mmol/1) & $1 \cdot 18$ & 0.36 & $1 \cdot 20$ & 0.23 & $1 \cdot 11$ & $0 \cdot 20$ \\
\hline Triacylglycerol (mmol/l) & $1 \cdot 31$ & 0.74 & $0 \cdot 89$ & 0.36 & $0.58^{*}$ & $0 \cdot 19$ \\
\hline Insulin $(\mathrm{ng} / \mathrm{ml})$ & $12 \cdot 1 * *$ & $8 \cdot 3$ & $2 \cdot 6$ & 1.9 & 1.9 & $0 \cdot 9$ \\
\hline GIP (pmol/1) & $126 \cdot 3$ & $36 \cdot 4$ & $130 \cdot 3$ & $33 \cdot 0$ & $103 \cdot 5$ & $21 \cdot 4$ \\
\hline
\end{tabular}

GIP, glucose-dependent insulinotrophic polypeptide.

Mean values were significantly different from those for other dietary groups: * $P<0.05,{ }^{* *} P<0.001$.

fed animals the difference did not reach statistical significance, this was due to the large degree of variation in the measurements. Two transcripts of LPL mRNA of approximately 3.7 and $1.7 \mathrm{~kb}$ in size were identified in adipose tissue but there was little expression in the liver. The mean LPL mRNA expression is shown in Figs. 4 and 5 for epididymal and perirenal fat respectively. These findings indicated a significant increase in LPL mRNA in the fish oil-fed group compared with the maize oil group in epididymal fat pads $(P<0.05)$ and in the maize oil-fed group compared with the other dietary groups in perirenal fat $(P<0.05)$. In addition, in the mixed oil-and fish oil-fed animals there was significantly higher expression in epididymal compared with perirenal adipose tissue. These findings suggest, therefore, that the effects of dietary fatty acids on LPL are controlled at a pretranslational 


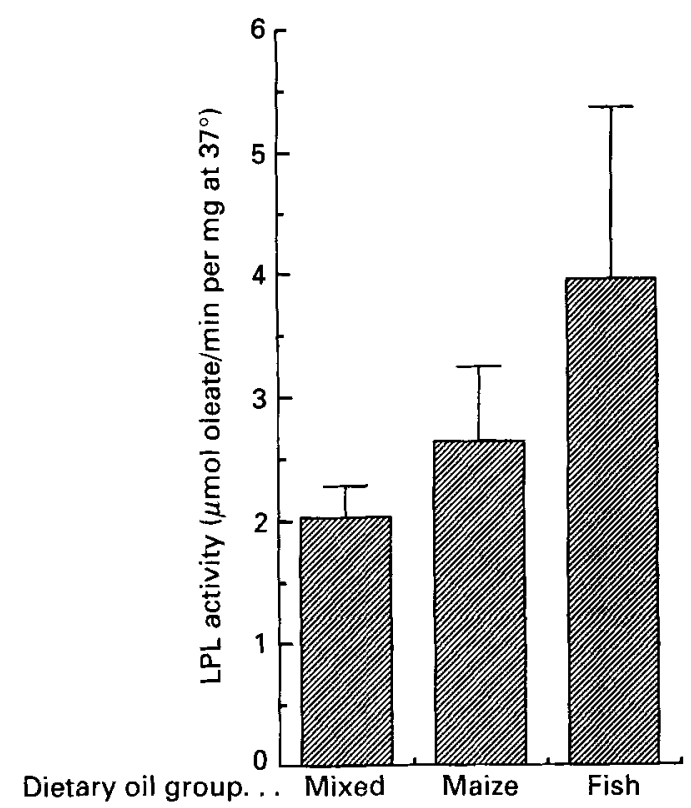

Fig. 3. Lipoprotein lipase (EC 3.1.1.34) activity in epididymal adipose tissue from rats pair-fed $50 \mathrm{~g}$ fat $/ \mathrm{kg}$ diets containing mixed, maize or fish oil for 2 weeks. Values are means with their standard deviations represented by vertical bars for eight rats per group. For details of dietary treatments, see Table 1 and p. 728.

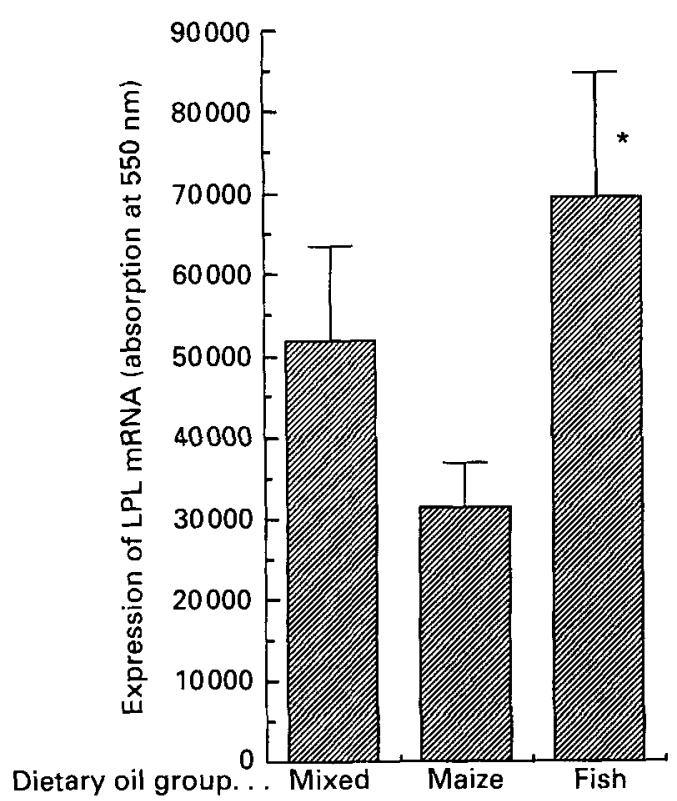

Fig. 4. Expression of lipoprotein lipase (EC 3.1.1.34) mRNA in epididymal adipose tissue from rats pair-fed $50 \mathrm{~g}$ $\mathrm{fat} / \mathrm{kg}$ diets containing mixed, maize or fish oil for 2 weeks. Values are means with their standard deviations represented by vertical bars for eight rats per group. Mean value was significantly different from that for the maize oil group: ${ }^{*} P<0.05$. For details of dietary treatments, see Table 1 and p. 728. 


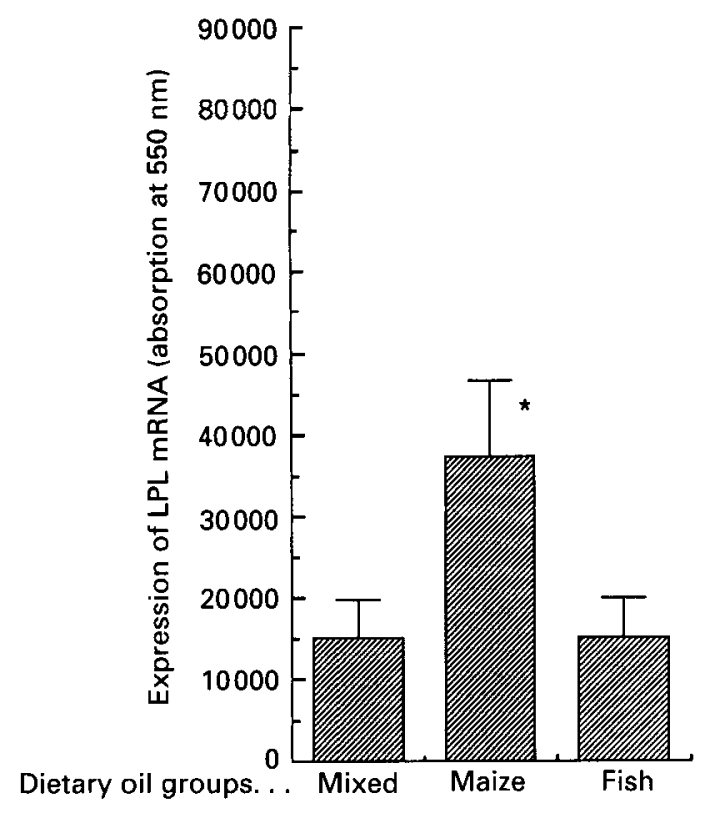

Fig. 5. Expression of lipoprotein lipase (EC 3.1.1.34) mRNA from perirenal adipose tissue from rats pair-fed $50 \mathrm{~g}$ fat $/ \mathrm{kg}$ diets containing mixed, maize or fish oil for 2 weeks. Values are means with their standard deviations represented by vertical bars for eight rats per group. Mean value was significantly different from that for the other dietary groups: ${ }^{*} P<0.05$. For details of dietary treatments, see Table 1 and p. 728 .

level. Insulin and GIP concentrations are given in Table 2 and show that fish oils did not increase plasma levels of insulin or GIP.

\section{DISCUSSION}

The fact that LPL is expressed as a number of transcripts was reported by Enerback et al. (1987) who identified four transcripts in guinea-pig epididymal fat pads of 4.5, 3.8, $3 \cdot 3$ and $2 \cdot 1 \mathrm{~kb}$, whereas Ong et al. (1988) indicated one $3.6 \mathrm{~kb}$ transcript in rat isolated adipocytes. Wion et al. (1987) noted that the two distinct LPL mRNA transcripts arose from alternative sites of 3'-terminal polyadenylation. Most workers have indicated none or very low expression of LPL mRNA in adult guinea-pig and rat liver (Enerback et al. 1987; Wion et al. 1987; Semenkovich et al. 1989).

The results of the present study support the view that diet can alter LPL through direct effects on LPL gene expression. This is the first time that effects at this level have been demonstrated in the adult animal for diets of different fatty acid composition. Ong \& Kern (1989) measured both LPL mRNA and immunoreactive mass and their findings suggested that human LPL was regulated post-translationally in response to feeding. This level of control of the fasting/feeding LPL response was also proposed by Doolittle et al. (1989) in humans. Simsolo et al. (1992) examined the effects of improved diabetic control on LPL activity and gene expression and their findings indicated that the regulation of LPL under these circumstances was at the translational level. These studies suggest that the rise in insulin levels produced on feeding stimulate an 'activation' of inactive LPL according to the theory of LPL secretion by Ailhaud (1990). On the other hand, Semb \& Olivecrona (1989) carried out detailed investigations into the regulation of LPL in the newborn guinea-pig and indicated that the fasting and refeeding LPL response was controlled at the transcriptional level in the neonate but that this level of regulation became less marked with age. 
There are previous studies which indicate that the degree of unsaturation of dietary fatty acids alters LPL activity (Paik \& Yearick, 1978; Groot et al. 1988), the greater the unsaturation the higher the LPL activity. These studies suggested that if the higher LPL activity is due to increased LPL gene expression then it would be predicted that fish oil-fed animals would have the highest LPL activity and mRNA levels, maize oil-fed animals the next highest and mixed oil-fed animals the lowest values. Although the LPL activity measurements in epididymal adipose tissue follow this trend, and the fish oil group had the highest production of mRNA in the same tissue, the production of LPL mRNA in perirenal adipose tissue showed a markedly different pattern, maize oil-fed animals having the greatest production of LPL mRNA compared with fish oil-fed and mixed oil-fed animals. A component of the variation in the expression of LPL mRNA between samples is a result of the higher coefficient of variation of this type of assay and may have masked any differences.

Regional differences in adipose tissue LPL activity measurements have been published from animal and human studies. Oben et al. (1991) showed in rats that LPL activity was higher in epididymal tissue compared with subcutaneous and omental adipose tissue and that epididymal tissue was more sensitive to stimulation by insulin and GIP. Human studies have compared femoral, gluteal and abdominal regions in relation to body fat distribution (Raison et al. 1988) but there has been little work indicating different effects of diet on different adipose tissue sites, particularly with respect to effects of diet on LPL mRNA levels. Our findings suggest that dietary fatty acid composition alters LPL gene expression and that two adipose tissue sites, perirenal and epididymal, respond differently to diets enriched with $n 3$ and $n 6$ PUFA. Site-specific differences in LPL mRNA response to $n 6$ and $n 3$ PUFA are unexpected. Furthermore, the levels of LPL mRNA within each tissue do not mirror the effect of the different fatty acids on circulating TAG levels. However, the expression of mRNA was considerably higher in epididymal compared with perirenal adipose tissue in mixed and fish oil-fed animals and, therefore, this tissue may have a more significant role in the plasma clearance of lipids. It is suggested that the alteration in LPL mRNA seen in the present study cannot provide the only explanation for fatty acid-induced changes in LPL activity.

The mechanism by which dietary fatty acid composition alters the gene expression for this enzyme is unclear. However, it would appear that it is not a direct effect of insulin or GIP. In the past it was assumed that insulin was the predominant hormonal regulator for adipose tissue LPL (Sadur \& Eckel, 1982) as decreases in LPL were shown in diabetes mellitus (insulin-deficient) and increases in the obese state (insulin resistance). However, although there are many studies showing a relationship between insulin levels and LPL activity, there is also evidence to show that the response is not entirely due to insulin. Insulin secretions in vivo are blunted in response to fructose compared with glucose whereas two studies have shown that there are no differences in LPL response to long-term diets isoenergetic for fructose and glucose (Vrana et al. 1974; Kannan et al. 1981). Results of the present study are consistent with the conclusion that the effects of dietary fatty acids on LPL mRNA are independent of changes in insulin secretion. However, the possibility remains that there may be altered sensitivity to the cellular actions of insulin in animals fed on PUFA-enriched diets. Altered sensitivity may be secondary to enrichment of membrane phospholipids with PUFA (Wahle, 1983; Tepperman \& Tepperman, 1985). Animals fed on the mixed oil diet had a high mean plasma insulin value (Table 2) with a wide scatter of individual values which is suggestive of a developing insulin resistance which may have resulted from the age of the animals and the fairly saturated fat diet.

Cryer (1987) reviewed the comparative biochemistry and physiology of LPL between species. Molecular size is similar and apolipoprotein C11 is a requirement for LPL activity 
in all species, but published values for catalytic efficiency measured in vitro differ considerably between rat and human studies (human milk $2250 \mu \mathrm{mol} / \mathrm{h}$ per mg (Hernell \& Olivecrona, 1982) compared with $5-15000 \mu \mathrm{mol} / \mathrm{h}$ per $\mathrm{mg}$ in rat adipose tissue (Parkin et al. 1982)). Whether these differences reflect enzyme activity in vivo is unclear. Direct comparisons are difficult due to the different tissues studied and the range of 'normal' diets. Cryer (1987) concluded that in mammals the changes in tissue LPL activities that occur in response to, for example, a $24 \mathrm{~h}$ fast are very similar. The factors affecting regulation of the LPL gene in the human, however, are unknown. Clearly these interesting findings require further investigation and preferably studies should be carried out in humans.

Acknowledgements go to Dr Oka for the donation of the cDNA probe. Many thanks go to Dr S. K. Howlett for her help in the production of the cDNA probe and with the techniques. This work was funded by the Southwest Regional Health Authority and the University of Surrey, Guildford, Surrey.

\section{REFERENCES}

Ailhaud, G. (1990). Cellular and secreted lipoprotein lipase revisited. Clinical Biochemistry 23, 343-347.

Bensadoun, A. (1991). Lipoprotein lipase. Annual Reviews in Nutrition 11, 217-237.

Chomczynski, P. \& Sacchi, N. (1987). Single step method of RNA isolation by acid guanidinium thiocyanatephenol-chloroform extraction. Analytical Biochemistry 162, 156-159.

Church, G. M. \& Gilbert, W. (1984). Genomic sequencing. Proceedings of the National Academy of Sciences USA 81, 1991-1995.

Cryer, A. (1987). Comparative biochemistry and physiology of lipoprotein lipase. In Lipoprotein Lipase [J. Borensztajn, editor]. Chicago: Evener Publishers Inc.

Cryer, A., Kirtland, J., Jones, H. M. \& Gurr, M. I. (1978). Lipoprotein lipase activity in the tissues of guinea pigs exposed to different dietary fats from conception to three months of age. Biochemistry Journal 170, 169-172.

Doolittle, M. H., Ben-Zeev, O., Elovson, J., Martin , D. \& Kirchgessner, T. G. (1989). The response of lipoprotein lipase to feeding and fasting. Journal of Biological Chemistry 265, 4570-4577.

Enerback, S., Semb, H., Bengtsson-Olivecrona, G., Carlsson, P., Hermansson, M.-L., Olivecrona, T. \& Bjursell, G. (1987). Molecular cloning and sequence analysis of cDNA encoding lipoprotein lipase of guinea pig. Gene 58, $1-12$.

Gotoda, T., Senda, M., Gamou, T., Furuchi, Y. \& Oka, K. (1989). Nucleotide sequence of human cDNA coding for a lipoprotein lipase (LPL) cloned from placental cDNA library. Nucleic Acids Research 17, 2351.

Groot, P. H, E., deBoer, B. C. J., Haddeman, E., Houtsmuller, U. M. T. \& Hulsmann, W. C. (1988). Effect of dietary fat composition on the metabolism of triacylglycerol-rich plasma lipoproteins in the postprandial phase in meal-fed rats. Journal of Lipid Research 29, 541-551.

Hampton, S. (1983). The C-Peptide of proinsulin, its diagnostic use and a possible physiological role. PhD Thesis, University of Surrey.

Harris, W. S. (1989). Fish oils and plasma lipid and lipoprotein metabolism in humans: a critical review. Journal of Lipid Research 30, 785-807.

Harris, W. S., Connor, W. E., Alam, N. \& Illingworth, D. R. (1988). Reduction of postprandial triglyceridemia in humans by dietary n-3 fatty acids. Journal of Lipid Research 29, 1451-1460.

Haug, A. \& Hostmark, A. T. (1987). Lipoprotein lipases, lipoproteins and tissue lipids in rats fed fish oil or coconut oil. Journal of Nutrition 117, 1011-1017.

Hernell, O. \& Olivecrona, T. (1982). Human milk lipases. 1. Serum-stimulated lipase. Journal of Lipid Research $15,367-374$.

Kannan, R., Baker, N. \& Bruckdorfer, K. R. (1981). Secretion and turnover of low density lipoprotein triacylglycerols in rats fed chronically diets rich in glucose and fructose. Journal of Nutrition 111, 1216-1223.

Levy, E., Roy, C. C., Goldstein, R., Bar-On, H. \& Ziv, E. (1991). Metabolic fate of chylomicrons obtained from rats maintained on diets varying in fatty acid composition. Journal of the American College of Nutrition 10, 69-78.

Morgan, L. M., Morris, B. A. \& Marks, V. (1978). Radioimmunoassay for gastric inhibitory polypeptide. Annals of Clinical Biochemistry 15, 172-177.

Nilsson-Ehle, P. \& Schotz, M. C. (1976). A stable, radioactive substrate emulsion for assay of lipoprotein lipase. Journal of Lipid Research 17, 536-541.

Oben, J., Morgan, L., Fletcher, J. \& Marks, V. (1991). Modification of lipoprotein lipase activity to gastric polypeptide (GIP) in rats incubated with triolein. Proceedings of the Nutrition Society 50, 190A.

Ong, J. M. \& Kern, P. A. (1989). Effect of feeding and obesity on lipoprotein lipase activity, immunoreactive protein and messenger RNA levels in human adipose tissue. Journal of Clinical Investigation 84, 305-311. 
Ong, J. M., Kirschgessner, T. G., Schotz, M. C. \& Kern, P. A. (1988). Insulin increases the synthetic rate and messenger RNA level of lipoprotein lipase in isolated rat adipocytes. Journal of Biological Chemistry 263, 12933-12938.

Paik, H. S. \& Yearick, E. S. (1978). The influence of dietary fat and meal frequency on lipoprotein lipase and hormone sensitive lipase in rat adipose tissue. Journal of Nutrition 108, 1798-1805.

Parkin, S. M., Speake, B. K. \& Robinson, D. S. (1982). Purification and characterisation of rat adipose tissue lipoprotein lipase. Biochemistry Journal 207, 485-495.

Raison, J., Basdevant, A., Sitt, Y. \& Guy-Grand, B. (1988). Regional differences in adipose tissue lipoprotein lipase activity in relation to body fat distribution and menopausal status in obese women. International Journal of Obesity 12, 465472 .

Raynolds, M. V., Awald, P. D., Gordon, D. F., Gutierrez-Hartman, A., Rule, D. C., Wood, W. M. \& Eckel, R. H. (1990). Lipoprotein lipase gene expression in rat adipocytes is regulated by isoproterol and insulin by different mechanisms. Molecular Endocrinology 4, 1416-1422.

Sadur, C. N. \& Eckel, R. H. (1982). Insulin stimulation of adipose tissue lipoprotein lipase-Use of the euglycemic clamp technique. Journal of Clinical Investigation 69, 1119-1125.

Semb, H. \& Olivecrona, T. (1989). Two different mechanisms are involved in nutritional regulation of lipoprotein lipase in guinea-pig adipose tissue. Biochemistry Journal 262, 505-511.

Semenkovich, C. L., Chen, S.-H., Wims, M., Luo, C.C., Li, W.-H. \& Chan, L. (1989). Lipoprotein lipase and hepatic lipase mRNA tissue specific expression, developmental regulation, and evolution. Journal of Lipid Research 30, 423-431.

Shimomura, Y., Tamura, T. \& Suzuki, M. (1990). Less body fat accumulation in rats fed a saftlower oil diet than in rats fed a beef tallow diet. Journal of Nutrition 120, 1291-1296.

Simsolo, R. B., Ong, J. M., Saffari, B. \& Kern, P. A. (1992). Effect of improved diabetes control on the expression of lipoprotein lipase in human adipose tissue. Journal of Lipid Research 33, 89-95.

Tepperman, H. M. \& Tepperman, J. (1985). Membranes and the response to insulin. Proceedings of the Nutrition Society 44, 211-220.

Van Heek, M. \& Zilversmit, D. B. (1990). Postprandial lipemia and lipoprotein lipase in the rabbit are modified by olive and coconut oil. Arteriosclerosis 10, 421-429.

Vrana, A., Fabry, P. \& Kazdova, L. (1974). Lipoprotein lipase activity in heart, diaphragm and adipose tissue in rats fed carbohydrates. Nutritional Metabolism 17, 282-288.

Wahle, K. W. J. (1983). Fatty acid modification and membrane lipids. Proceedings of the Nutrition Society $\mathbf{4 2}$, 273-277.

Wion, K. L., Kirshgessner, T. G., Lusis, A. J., Schotz, M. C. \& Lawn, R. M. (1987). Human lipoprotein lipase complementary DNA sequence. Science 235, 1638-1640. 